\title{
What does Óđinn do to the Túnriðor? An Interpretation of Hávamál 155
}

Frederik Wallenstein

Stockholm University

On the following pages I will attempt an interpretation of a wellknown, intensively discussed and deeply problematic part of the Eddic poem Hávamál, more precisely stanza I 55 - a part of the so called Ljóðatal section of Hávamál.

It is a well-known fact that Hávamál is by no means originally to be considered a single coherent work, but rather a compilation assembled, in all probability, before the scribe of the Codex Regius (c. I 270). Usually the poem is divided into several more or less independent parts, often five or six.

The so called Ljóðatal section, with which we are concerned here, is a clearly demarcated sequence of I 8 stanzas (I 46-I63) that has probably originally been an independent poem - even though it can be connected, in part, to for example Runatal (the apparent connection with Loddfáfnismál though, may well be due to a late interpolation). It consists of a list of г 8 lióð (magical songs/spells/charms) of which Óðinn claims knowledge and information about the function of each spell (even though the spells themselves are not included). These functions correspond quite well to Snorri's description in Ynglinga saga Ch. 6-7 of Óðinn's magical abilities, suggesting either that he knew Ljóðatal in some form or that he built his description on similar traditions/sources.

In stanza I 5 , the tenth of these lió is described in the following words:

Pat kann ec ip tíunda, ef ec sé túnriðor

Leica lopti á:

ec suá vinnc, at peir villir fara

How to cite this book chapter:

Wallenstein, F. 20I9. What does Óðinn do to the Túnriðor? An Interpretation of Hávamál I 5 5. In: Wikström af Edholm, K., Jackson Rova, P., Nordberg, A., Sundqvist, O. \& Zachrisson, T. (eds.) Myth, Materiality, and Lived Religion: In Merovingian and Viking Scandinavia. Pp. 397-42I. Stockholm: Stockholm University Press. DOI: https://doi.org/IO.I6993/bay.n. License: CC-BY. 
sinna heim hama, sinna heim huga. ${ }^{\mathrm{T}}$

Óðinn's tenth lióð is obviously a way of dominating other "air travellers" (who "play", "whirl" or simply "fly" in the air) thus asserting his superiority over them. The word túnriðor has been translated as "fence-riders" (ON tún, "enclosure", "fenced area") ${ }^{2}$ and these beings are usually interpreted in the light of a section of "Rättlösabalken" in the Swedish medieval law text $̈$ ldre Västgötalagen $\left(\mathrm{I} 3^{\text {th }}\right.$ century), relating punishments for insulting women. One of which is saying to a woman that:

Jak sa at pu reet a quiggrindu løsharep ok I trolls ham pa alt var iamrist nat ok daghér ${ }^{3}$

I saw that you rode the gate of the animal fold with loose hair and in the shape of a troll when everything was equal between night and day

We will not go further into the fascinating discussion concerning "fence-rider" as a terminus technicus for "air traveller" and/or "witch" 4 but only conclude that we can safely assume that we are dealing with females shapeshifters, flying in the air. This has, naturally, led many interpreters to understand this stanza in a more or less shamanistic frame of reference - one that I myself think is reasonable as long as we are aware that we are dealing with "shamanism" in the looser sense. The túnriðor are by no means to be considered shamans in the strict sense, but we can safely assume that they are performing a soul-flight. Whether or not this should be called "shamanism" is of little importance. The presence of a soul-flight is further underlined by the use of the concepts of hugr and hamr which are usually related to what historians of religion call free-soul-conceptions, i.e. aspects of the human soul or psyche that has the ability to temporarily leave the body. Hugr is a wide-ranging concept spanning most aspects of man's cognition (such as thought, wish, longing, etc.) but it also clearly signifies the aspect of the human soul believed to leave the body in states of sleep or trance. Hamr in similar contexts is the actual shape taken on by the hugr. In theory, this demarcation between the concepts is rather clear; in many actual cases, however, they are not so easy to differentiate, a fact we will return to shortly. 
Thus far the stanza seems quite comprehensible. But the way in which Óðinn asserts his dominance over the tunriðor is not so easy to ascertain. The last three lines of the stanza are problematic, and have been the subject of long and winding discussions, spanning well over a century of research history. The sheer number of suggestions as well as the imaginative power of some of them is quite staggering, but roughly speaking they can be grouped into two basic lines of interpretation (even though these two lines each span a wide range of interpretations as well as differing views of the syntax of the stanza).

I. Óðinn stops their soul-flight and forces them back to their bodies $^{6}$

2. Óðinn leads them astray, making it impossible for them to return to their bodies ${ }^{7}$

The second of these interpretations has been considered possible only by altering the text in one way or another. If we consider the syntax of the later part of the stanza, the problem lies in the syntactic position of the word heimr. Had it been in the genitive (sing. heims, plur. heima), this reading would have been very natural, but since it is here in the accusative, it is not possible to read it this way without some type of emendation. ${ }^{8}$ To my knowledge, no one has yet argued for changing the case of only the word heimr. Instead, the genitive form is usually produced by making compounds of the words heim and hamalhuga (heimhama, heimbuga), ${ }^{9}$ this has, for good reasons, been considered a lesser emendation. From this operation follows another problem, actually making sense of the two compounds thus produced. Heimhamr is unproblematic and quite self-explanatory it refers to the homeshape or the "usual shape" of the shapeshifter, i.e. the body that, left behind, lies inactive as the túnriðor are out flying in the air. The heimhugr, though, is harder to make sense of. The most usual, and best, attempt is taking heim- as meaning "the usual" or "wellknown" and thus interpreting heimbuga as "the normal mental state" of the túnriðor. ${ }^{\mathrm{I}}$ Although this translation of the otherwise unknown word is quite possible, it feels a little forced and almost ad hoc. It is hard not to feel that these interpreters really want Óðinn's lióð to lead the túnriðor astray rather than back to their 
bodies. As we will soon see, there is good reason for this (better, I think, than most of them realized), but at the same time the problems associated with the emendations made to the text must be considered a major disadvantage of this alternative. Even so, it has become the hegemonic reading of the stanza, followed in all newer editions and translations of Hávamál. ${ }^{\text {I }}$

On the following pages I will operate from the opinion that, if there is a plausible interpretation to be made without making emendations to the text, it is to be preferred. Before we return to the philological issues though, we need to look to the religio-anthropological context within which to interpret the conceptions discussed.

Seen in the light of comparative anthropological and folkloristic material, the interpretation that Óðinn leads the túnriðor astray and prevents them from returning to their bodies actually seems to make a lot more sense. The concept of "soul-loss" is well-known from the anthropology of religion. There are widely distributed conceptions of the dangers associated with the free-soul leaving the body and, for different reasons, not being able to return to it, either because it goes astray and does not manage to find its way back, or because its return is prevented by someone or something. This type of conception has not been discussed in relation to the interpretation of Hávamál I 55 (or, indeed, to Old Norse soul-conceptions in general). The comparative material that is of interest here is much too extensive for any type of exhaustive or systematic survey, and for our purpose a few illustrative examples from different contexts will suffice.

The Norwegian missionary Isaac Olsen, in his "Lappernes vildfarelser og overtro" (I 7 I 5 ) says of the Saami noaidi that he always has by his side a young female assistant who sings until he (i.e. his free-soul) returns to his body, and that she also sometimes has to look for him and bring him back so that he may wake up again. If she fails, says Olsen, the noaidi dies. He also tells of struggles between different noaidi and says that sometimes one noaidi may stop the soul of another and prevent it from returning to its body. "Many Noaidi die this way", says Olsen. ${ }^{22}$

The relevant comparative examples from Saami religion are many, but here we will limit ourselves to one more: the shamanic ritual described in Historia Norwegie. The unknown author here tells us of a group of Christians visiting Saami and witnessing how 
their hostess suddenly falls to the ground as if dead. The other Saami however tell them that she is in fact not dead but has been abducted by the gander of their enemies. Countermeasures are prepared: Their own "wizard" (magus), i.e. their noaidi, makes the necessary ritual preparations and puts himself into a state of trance to attempt to retrieve the soul of the woman. The results of these efforts are that the woman wakes up, but the noaidi dies, and we are told that he, on his soul-journey, had taken the shape of a whale and in this shape had been impaled by his adversary who had taken the shape of sharply pointed stakes. ${ }^{13}$ Before this though, he has apparently been successful in returning the soul of the woman to her body. The example thus contains two accounts of soul-loss: the theft of the woman's (free-?) soul and the soul of the noaidi that is prevented from returning to its body. Admittedly, it is not led astray but is killed, but the consequences are identical: the soul does not return to the body, and the body therefore dies.

These examples can be related to and, I think, enlightened by a wider comparative anthropological material concerning the concept of "soul-loss". Most of these are taken from more or less shamanistic contexts and cultures, even though the phenomenon itself is by no means limited to shamanistic cultures and religions in the strict sense - this is rather a consequence of the fact that soul conceptions, for natural reasons, have been thoroughly investigated in these areas.

If we begin with some examples from shamanistic areas, it is very clear that the soul-journey of the shaman is considered to be a very dangerous ordeal - primarily for the reason that the shaman may not (for different reasons) be able to return to his body. And when it comes to the shaman's responsibilities as a healer, one of the most common causes of illness is soul-loss, due either to the soul having wandered astray for some reason (for instance during sleep) or to soul-theft of some kind.

Symptoms of soul-loss, apart from death, physical decay, pain and mental problems, range from nervousness, memory loss and mental unbalance to complete madness. Sometimes the symptoms are related to what aspect of the soul has been lost and are usually deepened according to how long the soul has been lost. 
That these conceptions are central in many cultures in the so called "core area" of shamanism was evident already in the travelogues of early explorers as well as the anthropological overviews of Siberian peoples from the late $I 7^{\text {th }}$ and early $I 8^{\text {th }}$ centuries. $^{\mathrm{I} 4}$ Åke Hultkrantz says of conceptions of soul-loss among Native North Americans (in this case the Shoshoni):

If the free-soul does not return to the body, and the latter nevertheless returns to life, this may consequently signify that the person's possibilities of apprehending and understanding will be very small. He becomes 'queer', in a number of cases completely 'mad'. $[\ldots]$

the sickness must be cured sooner or later. i.e. the soul must be restored, if the patient is not to $\mathrm{die}^{\mathrm{IS}}$

These descriptions are very similar to the material presented by Ivar Paulson in his extensive collection and analysis of conceptions of the soul among Siberian peoples. He mentions on the one hand more or less temporary problems such as confusion, neuroses/psychoses, pain and fever, and on the other serious, chronic physical or psychic disease that usually ends with death. ${ }^{16}$

As already mentioned, these types of conceptions are by no means limited to shamanistic cultures in the strict sense, nor are they limited to Scandinavia or even the North-Eurasian area, but seem to be of a very general nature. Carlo Ginzburg, for example, in his famous investigation of the Friulian Benandanti in the late fourteenth and early fifteenth centuries, says that:

These benandanti say that when their spirit leaves the body it has the appearance of a mouse, and also when it returns, and that if the body should be rolled over while it is without its spirit, it would remain dead, and the spirit could never return to it. ${ }^{17}$

Similar conceptions are to be found in Nordic folklore material ranging from the fifteenth up to the early twentieth century. This is especially true of the material in the collections of the folk-memory archives, dealing primarily with material from the late I $800 \mathrm{~s}$ and the early I90os. Conceptions of soul-loss are referred to with words like being vordstolen (one whose "vård" has been stolen) or vordlaus (being without "vård"), or hamstolen, hamslaus, etc. 
The concept of being hamstolen also has a direct counterpart in Icelandic sagas (being hamstolinn or hamslaus) where it means "having lost one's wits" ${ }^{18}$ It is the case, for example in the famous episode in Egils saga where the young woman Helga has been made ill by the failed attempts at rune magic by a young farmers son. ${ }^{19}$ It is worth noting that this meaning of the word, though not (still?) specifically referring to soul-loss, is completely in line with the thought consequences of soul-loss referred to above, and one may at least wonder whether there is an older conception concealed behind the word as it is used in the sagas.

Nils Lid has discussed a Norwegian trial from I660 where a woman knowledgeable in the art of witchcraft says that the "word" (voord, vård, vål, etc.) that sits in man's breast is out at night flying around, and that if then a spirit takes it and it is not able to return to the body, that person loses their sanity:

Der er it word i mennischens bryst, som faar ude om natten, naar dj soffer. Och dersom der da kommer en vnd and offuer den, saa den iche kommer igien till mennischen, saa bliffuer det mennische aff med sin forstand ${ }^{20}$

Conceptions about the risks associated with losing the "vård" have been very widespread, at least in Swedish and Norwegian folklore, and have been especially connected to being suddenly and/or very frightened (vålskrämd, voordskramd, etc.) and just like in the case of poor Helga in Egils saga, this was considered as leading to "losing one's mind" or "losing one's wits". Another illustrating example can be found in Jón Árnason's (I 8 I9-I 888) Íslenzkar pjóðsögur og afintýri (I 862-1864). Here it is said of the priest Eiríkur (Magnússon) i Vogsósum (I667-I7I6) that one time when he was out on a gandreið his body was found by two boys and that when he returned he thanked them for not having touched the body; had they done so, he says, he would not have been able to return. ${ }^{21}$ It should be added, though, that even though there are a few more episodes in this material that could be interpreted in the same vein (some referring to the same Eiríkur), it is hard to find any that are as clear-cut as this one and therefore it is hard to draw any definite conclusions about the occurrence of this conception in Icelandic legend and folklore. 
From general folklore one could also mention the very widespread conception of the dangers associated with being woken suddenly. Often this is explained by the risk that the soul does not manage to return before the body wakes up, resulting in its inability to re-enter the body. This is common not only in Nordic folklore, but from almost all over the world, and it is not seldom associated with mortal danger. Ivar Paulson for instance, in his book on the soul-conceptions of Siberian peoples writes that several of these peoples "ausdrücklich verbietet, einen Schlafenden vor seinem natürlichen Erwachen zu wecken, da sonst die Seele 'draussen' bleiben kann". ${ }^{22}$

As mentioned previously, the comparative material is very extensive and we could give other examples of this kind for quite some time, but thus far I think we can safely conclude that, while the conceptions of the dangers associated with the soul (or parts of the soul) leaving the body and not being able to return are very widespread and are always associated with grave illnesses and death, magical or religious conceptions of the forcing back of an individual's soul into their body is, as far as I can see, virtually unknown. The conception of soul-loss is more often than not associated with conceptions of especially gifted and powerful people being able to steal and/or (as a countermeasure for this) return the souls of others, but there does not seem to be any examples of shamans, magicians or others forcing the souls of others back into their bodies. ${ }^{23}$

Summarizing the problem, we can conclude that it seems that the wish to read the manuscript without emendations is at odds with the most reasonable interpretation of the stanza. On the one hand we have a line of interpretation that leaves the manuscript untouched and on the other we have one that seems to make a lot more sense but that is forced to make alterations to the manuscript. But let us go back to the first line of interpretation once more. Here we have at least three readings of the stanza that leaves it without emendations (Fredrik Leopold Läffler, Björn Magnus Ólsen and Dag Strömbäck). Of these three, the most interesting and persuasive one is that made by Strömbäck. ${ }^{24}$ In fact, on closer examination it seems that the way Strömbäck reads the stanza may actually contain other interpretive possibilities than the one presented either by him or his commentators. 
One of the cornerstones in Strömbäck's view of the stanza is his persuasive discussion showing that, even though they are in some cases clearly separable concepts, the words hugr and hamr should in this case be considered as synonyms, both denoting the "freesoul", and that, accordingly, the "heim hama", and "heim huga" are synonymous expressions meaning the home of the hamir and hugir, i.e. the home of the (free-)souls (of the tunriðor), thus eliminating a source of major problems for many of the preceding interpreters. ${ }^{25}$ With this in mind, let us go back to the syntactic issues.

As mentioned, the basic problem is the syntactic position of the word heim. Had this word been in the genitive plural (heima), says Strömbäck, we would have had an excellent translation: "they go astray, in relation to the home of their souls", but, since it is obviously in the accusative, this interpretation is not possible. He then goes on to give persuasive examples from Eddic as well as skaldic poetry of how the accusative marks the goal of the motion verb. Arguing that the direction of the movement in this case must be towards the bodies (the heim hama, heim huga) of the tunriðor. Since there is no preposition, we cannot say whether they go, to their bodies, into their bodies or perhaps towards their bodies, but from the syntax we can conclude that the direction of the movement is clear beyond doubt. Reading the stanza this way, villir has to refer to the mental state of the tunriðor. They go, confused, towards the home of their souls. Strömbäck uses the Swedish word "förvillade" - "confused" or perhaps "mentally astray".

Thus, concludes Strömbäck, Óðinn's lióð makes the tunriðor "villir fara sinna heim hama, sinna heim huga" - "go, confused, back to the home of their souls" ${ }^{26}$ meaning that Óðinn confuses them, takes control over their soul-flight and forces them back to their bodies.

Strömbäck's view of the syntax is very persuasive and I see no grounds for criticising it, but his interpretation (and his translation) does not follow from it logically as the only one possible. As mentioned above, the critical word "to" could just as well be replaced by "towards" (since there is no such exact preposition), which would give a slightly different translation, saying that the túnriðor "go, confused, towards the home of their souls". 
Well then. What does it actually mean to "confuse", to make someone go mentally astray, at the point of return to the body?

It is actually only said that at the point of return, when they go back, they are attempting to re-enter their bodies, Óðinn has thrown the tunriðor into a state of confusion, making them go mentally astray. ${ }^{27}$ The way I see it this could just as well mean that the tunriðor are in a mental state that prevents them from re-entering their bodies, or indeed from actually finding their way back!

If this interpretation has any bearing, we can read the stanza exactly the way that Strömbäck does, but still interpret it according to the other line of interpretation. Óðinn knows a lióð with which he asserts his dominance over other beings whose souls are out flying. With it, he has the power to prevent them from returning to their bodies, resulting in the gravest of consequences: he annihilates them.

I would argue that this interpretation is preferable from a philological perspective, as well as a cultural- or a religio-historical, or, indeed, a poetic perspective. It requires no emendations of the manuscript and it does not have to deal with neologisms that are hard to interpret (heimhugr). From a comparative religioanthropological perspective, it is supported by an overwhelming number of parallels (while the competing line of interpretation seems to have none) and from a closer cultural-historical perspective it is coherent with what we know of Old Norse soulconceptions. It is also, I would argue, more in line with what we know of Óðinn. Destroying his opponents is a more likely action than just stopping their soul-flight and forcing them back. And, at least in my opinion, this much more dramatic action makes more poetic sense in a stanza describing the magic abilities of Óðinn.

Perhaps we even have a few more examples of the concept of soul-loss in Old Norse material. We have already seen a possible remnant of such conceptions in the above-mentioned episode in Egils saga Skalla-Grimssonar and there may be others. In closing, we shall look at one such possible instance.

Strömbäck discusses an interesting detail mentioned in GqnguHrólfs saga. In this saga the dwarf Mondull who is skilled in magic uses something called seiðvillur to sabotage the practice of seiðr 
by somehow "confusing" the seiðmenn. ${ }^{28}$ The use of the word villr is of course significant and Strömbäck sees the similarities with Óðinn's tenth lióð, but considers the described consequences of the practice as unexpected if (as he would argue) its purpose is forcing back the free-souls of these seiðmenn to their bodies. The seiðmenn are in fact acting completely insanely. They break their seiðhjallar, run around totally disoriented and die by running off cliffs and into marshes. This all seems mysterious to Strömbäck. If, though, such an effect can be associated with the return of the souls to their bodies, he says, "then the magic song alluded to in the Hávamál-stanza is given an even greater power". ${ }^{29}$

If, however we, like Strömbäck, are to take the details provided in Gongu-Hrólfs saga of this magical practice seriously, the interpretation must again be altered according to the interpretation presented here. In fact, if we view it in the light of what has been said above on the widespread conceptions of the consequences of soul-loss the description of the seiðvillur actually seems to make all the more sense. Indeed, the description of the consequences befalling the seiðmenn corresponds completely to this. This is thought-provoking: perhaps this otherwise quite imaginative fornaldarsaga has actually kept the memory of a magical practice functionally equivalent with Óðinn's tenth lióð.

Lastly, I would like to add an interesting detail. And quite an odd one. When reading an article by Strömbäck's hand, published 40 years after the dissertation, I found an en passant mention of Hávamál I 55, where he had this to say:

Odin knows the charms by which they [i.e. the túnriðor] can be put out of action. Through him they are led astray and cannot find the place from where they have started their journey, the place where their hamir and hugir have started their journey ${ }^{30}$

This is, quite obviously, a completely different interpretation from the one he gives in the dissertation, but in the article, he only refers to his own book in the following words:

I have tried in my time to give stanza I55, which has been discussed by at least two generations of philologists before me, a reasonable interpretation and I shall not now go further into that linguistic matter (Sejd, p. I68-I 82) (3I $^{\text {I }}$ 
These words are quite surprising, to say the least. Since this is exactly the interpretation that he deems impossible on philological grounds on precisely the pages referred to.

What happened to Strömbäck's view of the stanza we will never know. The fact that he would have been persuaded by the arguments of Finnur Jónsson and others seems very unlikely since he was very reluctant to make emendations to the manuscript and argued forcefully against this line of interpretation. Maybe he never changed his mind concerning the syntax. Maybe he came to see the stanza in the way I do! But, in that case, he never explained the grounds on which he changed his mind. His silence on this point, much like Óðinn's lióð, makes one feel rather confused.

\section{Notes}

I. Neckel/Kuhn I962.

2. Franck I901:668; Noreen I922-I924:59-60. For other (decidedly less convincing) explanations of the word, see e.g. Fritzner I954 (г 883-г 896), III:73 I; B.M. Ólsen r9 16:7 I.

3. Äldre Västgötalagen RB V:5, in Wiktorssons edition II:88.

4. But it is worth mentioning the etymological discussion on the word "häxa" (German hexe) where OHG hagazussa has been interpreted as meaning "fence-woman". See Noreen I922-I924:60-6I. On OHG hag- see Noreen I922-I924:60; Fick et al. I 909:68.

5. Since the tunriðor are female, the form peir villir is unexpected. One would rather expect the feminine poer villar. This has often led to emendations of the text. Strömbäck, though, wanted to leave the text unchanged and referred to the possibility of there also being male tunriðor (Strömbäck I935:I8I-I82).

6. This is the case with e.g. both Fredrik Leopold Läffler and Björn Magnus Ólsen who debated the stanza in the two Swedish philological journals Studier i nordisk filologi and Arkiv för nordisk filologi a little over a hundred years ago (see Läffler I9I 4; I9I 6; Björn Magnus Ólsen r9r6). Also, Dag Strömbäck, who devoted a detailed study to the stanza in his dissertation on seiðr in 1935 , was of the opinion that 
Óðinn forced the free-souls of the túnriðor back into their bodies. This, of course, was the only thing they agreed on in their in every other way very different interpretations. The case of Strömbäck's view is especially interesting, and more complicated than one might first realize, a fact I will return to shortly.

7. This interpretation was perhaps most forcefully expressed in the work of Finnur Jónsson (Finnur Jónsson 1924; Sveinbjörn Egilsson \& Finnur Jónsson I93I), but has been argued in different variants by many scholars both before and since (for the sake of chronology, it should perhaps be pointed out that Finnur Jónsson's views on the stanza are presented already in Sveinbjörn Egilsson \& Finnur Jónsson I913-1916). Early proponents are e.g. Guðbrandur Vígfússon (I883), and, as it seems, even earlier, Fínnur Magnusson (although his is an uncommented translation), see Fínnur Magnusson I 822:I 42. It was adopted early also by Magnus Olsen (Olsen I9I I:32-33; I9I7:629) and, in a way, also by Hugo Gering (1904; I927), although his emendations go further, also changing -huga to -haga).

8. The philological issues are presented very clearly by Dag Strömbäck (Strömbäck I935:I77ff.).

9. For details see the literature referred to above.

Io. This is the interpretation made in the Íslenzk Fornrit edition (see p. 354), as well as Gísli Sigurðsson's edition (I999:57), but it has been argued in variants for a long time. The way I see it, this must be the interpretation made already by Finnur Magnusson in his translation from I 822 (Finnur Magnusson I 822:I42). It is also what lies behind the words chosen by Larrington ("their minds left at home") and Orchard ("their proper minds"). It did not impress Hugo Gering (I904; I927) though, who changed it to heimhaga ("heimstätte"), nor Finnur Jónsson who considered the last line to be either "unecht" or a bad variant of the preceding line (I924; I93 I).

II. See, for instance, the English translations by Larrington (I996; 20I4) and Andy Orchard (20II) and the editions by Evans (I986) and Dronke (2OII) as well as the Íslenzk Fornrit edition from 20I 4 and the edition by Gísli Sigurðsson from 1999. The same goes for the influential edition by Guðni Jónsson (1949). 
I 2. "saa skal hun Joige og Runne saa lenge at hand op vogner igien, og hun skal leede efter hannem med sin konst i hvor hand foer hen, indtil at hun finder hannem, og naar hun da har fundet hannem, saa fører hun hannem til bage igien og saa vaagner hand op igien, de sige self at de finder hannem under tiden i bierge huller langt borte i marcken, Ja og somme tider i Helvede og under Jorden, saa og i vandene, og der som hun er icke forstandig nock, eller icke vel lært, som skal leede effter Noiden, og hun icke med sin konst kand finde hannem, og føre ham til bage igien, saa døer hand viserlig med det samme og aldrig op vogner mer igien"

$[\ldots]$

"om en annan Noid er vred paa hannemm den samme som ducker under, eller har hafft eller har strid tilsammen, med konsten, og de vill vide hvem som skal være En andens mæstere og over mand i deris konsters strid saa paßer den anden paa i det samme, som hand ducker under, og stopper vejen til for hannem og formeener hannem at kommet til bage igien, og naar det saa er Da døer Noiden ogsaa og aldrig op vaagner meere, Det er mange af Noiderna som saaledis døer i den Zammelli eller ducke færd, i deris troldmesße"

(Olsen, Lappernes vildfarelser og overtro I9 Io (I 7 I 5):45-46).

I3. Historia Norwegie IV, "De Finnis": I6-24.

I4. E.g. Bogoraz I975 (I904-I909):332-333 ; Jochelson I905:4 I, 6I, IоI ; Stadling I9г2:19, 24, 93, 96, 98, 99-100, I16, I2I ; Czaplicka I9I4:260-26I, 282, 287; Nioradze I925:2Iff., 44-45; Shirokogoroff I935:I35-I36, 3 I7-3 I 8 .

15. Hultkrantz 1953:286-287. On the concept of soul-loss in Hultkrantz material, see Hultkrantz I953:285-29I.

I6. Paulson I958:273, 292, 298-303.

I7. Ginzburg 20I3 (I966):I8. This is just one of many instances of this conception in Ginzburg's book. It reoccurs many times in the protocols of the inquisition hearings on which Ginzburg builds his investigation. It also mentions the risks associated with touching, or even looking at the body when the soul has left it. Ginzburg also gives 
instances of the conception from a wider area (stretching from Alsace to the eastern parts of the Alps), and further back in time (at least a couple of hundred years).

I8. Fritzner: "berøvet sit For-stand", Fritzner I954 (I883-I896) I:719.

19. Egils saga Skalla-Grimssonar, Ch. 72 (ÌF II:229).

20. Lid I935:I2.

2I. This episode is also retold by Dag Strömbäck (Strömbäck I 935 :I90).

22. Paulson I958:292. Mircea Eliade says of conceptions among Native North Americans: "The soul leaves the body during sleep, and one may kill a person by waking him suddenly. A shaman must never be startled awake" (Eliade I964:30I).

23. At this point I should perhaps clarify that the point of these wide-ranging anthropological and folkloristic comparative examples is not to suggest long winding threads of cultural/religious continuity or lines of diffusion or anything like that, it is merely to show that these conceptions are very widespread and general in nature and to suggest that it seems very reasonable to think that this material sheds light on what is going on in this stanza. I am not fishing for the origin of these conceptions or suggesting that they are indicative of certain cultural connections, even though these questions are indeed interesting and worthy of further study.

24. Strömbäck I935:I68-I 82.

25. Strömbäck I935:I72, see also I73-I77.

26. "Förvillade fara till sina hamnars hem, till sina själars hem" (Strömbäck I935:I79-I80).

27. On other types of Old Norse conceptions of magic intended to cause similar conditions, see Gunnell 20I4.

28. Gqngu-Hrólfs saga, Ch. 28; Strömbäck I935:I8I, on his view of Gongu-Hrólfs saga see also гоo-102.

29. Strömbäck I935:I8I.

30. Strömbäck I 975:20.

3I. Strömbäck I 975:20. 


\section{References}

\section{Primary sources}

Edda. Jónas Kristjánsson og Vésteinn Ólason. 20I4. Eddukvœei I. Goðakvæði. Jónas Kristjánsson og Vésteinn Ólason gáfu út. Reykjavík: Hið Íslenzka Fornritafélag.

Gísli Sigurðsson. I999. Eddukvæði. Gísli Sigurðsson sá um útgáfuna. In Mál og menning.

Guðni Jónsson. I949. Eddukvœði (Samundar-Edda). Fyrrir bluti. Guðni Jónsson bjó til prentunar. Reykjavík: Íslandingasagnaútgáfan.

- Neckel, Gustav \& Kuhn,Hans. I962. Edda.Die Lieder des Codex Regius nebst verwandten Denkmälern. I Text. Vierte umgearbeitete Auflage von Hans Kuhn. Heidelberg: Carl Winter Universitätsverlag.

- Gering, Hugo \& Hildebrand, Karl. I904. Die Lieder der Älteren Edda (Scemundar Edda). Herausgegeben von Karl Hildebrand, Zweite völlig umgearbeitete Auflage von Hugo Gering. Paderborn: Ferdinand Schöningh.

Magnusen, Finn. 1822-1823. Den celdre Edda. En samling af de nordiske folks aldste sagn og sange ved Samund Sifussön. Oversat og forklaret ved Finn Magnusen. København: Den Gyldendalske Boghandling.

- Larrington, Carolyne. 20I4. The Poetic Edda. Translated with introduction and Notes by Carolyne Larrington. Revised edition. Oxford: Oxford University Press.

Larrington, Carolyne. I996. The Poetic Edda. Translated with introduction and Notes by Carolyne Larrington. New York: Oxford University Press.

— Orchard, Andy. 20I I. The Elder Edda. A Book of Viking Lore. Translated and edited by Andy Orchard. London: Penguin books.

Äldre Västgötalagen. Wiktorsson, Per-Axel (ed). $201 \mathrm{I}$. Äldre Västgötalagen och dess bilagor $i$ Cod. Holm. $B$ 59. Värnamo: Föreningen för Västgötalitteratur.

Gongu-Hrólfs saga. Guðni Jónsson \& Bjarni Vílhjalmsson (eds.). I944. Fornaldarsögur Norðurlanda II. Reykjavík: Bókútgáfan Forni. 
Historia Norwegie. Ekrem, Inger \& Mortensen, Lars Boje (ed.). 2003. Historia Norwegie. Transl. Peter Fisher. Copenhagen: Museum Tusculanum Press.

Isaac Olsen, Om Lappernes vildfarelser og overtro (I 7 I 5 ). Qvigstad, J. (ed.). I9 Iо. Kildeskrifter til den lappiske Mythologi 2. Trondhjem: Det Kgl. Norske Videnskabers Selskab.

Secondary literature

Björn Magnus Ólsen. I9ı6. Hávamál v. I 55. In Arkiv för nordisk filologi 32 .

Bogoras, Waldemar. (Bogoraz, Vladimir). I975 (I904-I909). The Chukchee. The Jesup North Pacific Expedition. Vol VII. New York: AMS Press Inc.

Czaplicka, Marie A. I9I4. Aboriginal Siberia. A Study in Social Anthropology. Oxford: Claredon Press.

Dronke, Ursula. 2or I. The Poetic Edda. Vol. 3, Mythological poems 2. Oxford: Clarendon.

Eliade, Mircea. 1964. Shamanism. Archaic Techniques of Ecstasy. Princeton: Princeton University Press.

Evans, David A.H. I986. Hávamál. London: Viking Society for Northern Research.

Fick, August et al. I909. Wörterbuch der indogermanischen Sprachen. Dritter Teil: Wortschatz der Germanischen Spracheinheit. Unter Mitwirkung von Hjalmar Falk gänzlich umgearb. von Alf Torp.

Finnur Jónsson. I924. Havamal. København: Gads forlag.

Franck. I90I. Geschichte des Wortes Hexe. In J. Hansen (ed.). Quellen Und Untersuchungen Zur Geschichte Des Hexenwahns Und Der Hexenverfolgung Im Mittelalter. Bonn: Carl Georgi, UniveritätsBuchdruckerei und Verlag.

Fritzner, Johan. I954 (I883-1896). Ordbog over Det gamle norske Sprog. Oslo: Møller.

Gering, Hugo. I927. Kommentar zu den Liedern der Edda. Erste Häfte, Götterlieder. Von Hugo Gerling; nach dem Tode des Verfassers herausgegeben von B. Sijmons. Halle: Buchhandl. des Waisenhauses. 
Ginzburg, Carlo. 2013 (1966). The Night Battles, Witchcraft and Agrarian Cults in the Sixteenth and Seventeenth Centuries. Translated by John \& Anne Tedeschi. Baltimore: John Hopkins University Press.

Guðbrandur Vigfússon (ed.). I883. Corpus Poeticum Boreale. 2 vols. Oxford: Clarendon.

Gunnell, Terry. 20I4. 'Magical Mooning' and the 'Goatskin Twirl', 'other' Kinds of Female Magical Practices in Early Iceland. In T. Tangherlini (ed.). Nordic Mythologies, Interpretations, Intersections, and Institutions. Berkeley \& Los Angeles: North Pinehurst Press.

Hultkrantz, Åke. 1953. Conceptions of the Soul among North American Indians. A Study in Religious Ethnology. Stockholm: Etnografiska museet.

Jochelson, Waldemar. I905. The Koryak, part I. Leiden: Brill.

Lid, Nils. I935. Magiske fyrestillingar og bruk. In Nordisk kultur XIX. Albert Bonniers förlag.

Läffler, Fredrik Leopold. I9I4. Om några underarter av ljóðaháttr. Bidrag till den fornnorsk-fornisländska versläran och till textkritiken av Eddasångerna, tillika en studie över Háttatals strof ıо . In Studier i nordisk filologi 5 . Helsingfors: Svenska litteratursällskapet.

Läffler, Fredrik Leopold. I9ı6. Till Hávamáls strof I 5 5. In Arkiv för nordisk filologi 32.

Nioradze, Georg. 1925. Der Schamanismus bei den Sibirischen Völkern. Stuttgart: Strecker und Schröder.

Noreen, Erik. 1924. Om ordet häxa. In språkvetenskapliga sällskapet $i$ Uppsalas förhandlingar, Uppsala universitets årsskrift I924:2. Uppsala: Almqvist \& Wiksell.

Olsen, Magnus. I9ı. En indskrift med ældre runer fra Huglen i Søndhordland. In Bergens museums Aarbok I9I I.

Olsen, Magnus. I9I7 Norges indskrifter med de ældre runer II. Christiania: A.W. Brøggers bogtrykkeri.

Paulson, Ivar. 1958. Die primitiven Seelenvorstellungen der nordeurasischen Völker. Eine religionsethnographische und religionsphänomenologische Untersuchung. Stockholm: Etnografiska museet. 
Shirokogoroff, S.M. I999 (I935). Psychomental Complex of the Tungus. Berlin: Reinhold Schletzer Verlag.

Stadling, Jonas. I9I 2. Shamanismen i Norra Asien. Stockholm: P.A. Norstedt \& söner.

Strömbäck, Dag. I989 (I978). Om de nordiska själsföreställningarna. In Den osynliga närvaron. Studier i folktro och folkdikt. Hedemora: Gidlunds förlag.

Strömbäck, Dag. I935. Sejd. Textstudier i nordisk religionshistoria. Stockholm: Gebers Förlag.

Strömbäck, Dag. I975. The Concept of the Soul in Nordic Tradition. In $A R V$.

Sveinbjörn Egilsson, \& Finnur Jónsson. I9I3-I916. Lexicon poeticum antiquae linguae septentrionalis - Ordbog over det norsk-islandske skjaldesprog. København: Det kongelige Nordiske Oldskriftselskab.

Sveinbjörn Egilsson \& Finnur Jónsson. I93 I. Lexicon poeticum antiquae linguae septentrionalis - Ordbog over det norsk-islandske skjaldesprog (2 Udgave). København: Det kongelige Nordiske Oldskriftselskab. 


\section{Response}

Terry Gunnell

University of Iceland

It should be stated immediately that, while I am a little uncertain about both hugr and hamr being one and the same thing (in short, both the "soul" and the "shape taken on by the hugr", which would appear to me to be different things), I find the overall argument made by Fredrik Wallenstein with regard to st. I 55 of Ljóðatal convincing, not only philologically but also in terms of Old Nordic religious beliefs and later folklore from the Nordic area. In the short response to the paper which will follow, I will essentially be providing further evidence that can be used to support the idea (and the wider consequences of supernatural figures becoming villir 'losing direction'). However, I will also make some suggestions with regard to explaining the apparent change of sex of the tunriðor and the possible meaning of that word (with reference to something other than witches as 'fence riders').

It might be said that the most obvious support for the argument made by Wallenstein is found in the detailed account of Porbjorg litilvolva's seiðr activities given in Eiríks saga rauða where Porbjorg asks a group of women to assist her by singing a varðlokr/ varðlokkr (the spelling varies by manuscript: see Eíríks saga rauða: 206-9). As Stephen Mitchell has effectively argued, ${ }^{\mathrm{I}}$ the word in question seems to refer to a "calling song" designed to call the spirit of the seiðr practitioner back to her body from a shamanistic journey. The implication is that her activities place her travelling hugr in danger of getting lost, and that it needs to be called back safely from the "other side" by the chant in question. While Mitchell sees the first part of the word as referring to women (vqrð), as he notes it might also refer to protective spirits of various kinds (vorðr/ verðir), as applies in the case of the Norwegian gardvord, a word used in later Norwegian folklore for the farm protective spirit (cf. the nisse or tomte in Swedish and Norwegian ${ }^{2}$ ).

In a recent article entitled "'Magical Mooning' and the 'Goatskin Twirl': 'Other' Kinds of Female Magical Practices in 
Early Iceland", 3 I have noted that the idea of "confusing" nature spirits by means of causing them to lose direction so that they cannot find their way home (invoking a sense of madness) is found on several other occasions in Old Norse literature: in the Jarlsnið curse (and so-called pokuvisur (lit. 'fog-verses')) which Porleifr jarlsskáld uttered against Jarl Hákon in Prándheimr, in Porleifs páttr jarlsskálds (Ch. 4-5); in the curses that accompany Egill Skallagrímsson's erection of a niðstong ('scorn pole') against King Eiríkr blóðöx in Egils saga (Ch. 57) in which Egill magically attempts to bring about a situation in which the landvottir or 'land spirits' fari [...] villar vega, engi hendi né hitti sitt inni (lose their way, and do not reach or find their home); and in the similar Busluboen in Bósa saga ok Herrauðs (Ch. 5), which also attempts to create a chaotic situation by means of magic: Villist voettir,/ verði ódomi,/ hristist hamrar,/ heimr sturlist,/ versni veðrátta;/ verði ódoemi (May the spirits lose their way, may there be nothing like it,/ the cliffs shake,/ the world go mad,/ the weather worsen;/ may there be nothing like it), which uses the same verb (að villa). Once again, the stress is on supernatural spirits getting lost while travelling. Indeed, a similar idea seems to be evident in Voluspá, st. 50 , where, as an image of the ultimate chaos that will come about at ragnarøk, the volva tells of how stynia dvergar/ fyr steindurom,/ veggbergs visir (the dwarfs will groan/ before stone doors/ the cliff face princes). Here it should be remembered that the dvergar are said to secure the cardinal directions in Gylfaginning, Ch. 8. As noted in the aforementioned article, several other saga references describe magical rituals which seem to be deliberately designed to invoke a similar kind of chaos in nature, and there is good reason to believe that the same idea lies behind the protective curse in Hávamál, st. I 55. Indeed, in a world in which sea travel and journeys over mountain passes were commonplace, one can well understand the importance of knowing directions and finding your way home, and the degree to which losing it might be associated with a state of ultimate confusion, chaos and madness.

With regard to the element of an apparent change of sex that seems to occur in Hávamál, st. I 55, as the feminine túnríor become peir, it is worth considering that a similar thing actually seems to take place in Niáls saga (Ch. I 57) in the account of the 
performance of Darraðarljóð in which first we read that menn riðu tólf saman til dyngju nokkurrar ok hurfu par allir (twelve men rode together to a women's bower, and all of them disappeared) (my bold italics), and then soon afterwards that a group of women were seen chanting verses: poer kvádu pá vísur nokkurar (they [the women] then sang/ chanted some verses). While the possibility naturally exists that the word menn here refers to people in general, it does seem that the idea of some kind of inversion (often sexual) commonly formed part of female magic practices in the Old Norse world. I have dealt with this in more detail in the article referred to above, especially with reference to magic practices that relate in some way to the "other world" of death and the disir, in which women commonly take on the stereotypical male role of ruling, riding horses and bearing weapons. ${ }^{4}$

Bearing the aforementioned disir in mind, and considering the word tunriðor itself, there is also good reason to consider the account of how two groups of disir are said to ride onto the vollr of a farm during the Winter Nights in Piðranda páttr ok Pórhalls (Ch. 2); the accounts of the threats posed by the figure of the ogress Grýla/ Skekla, who is also said to come down onto farms at various turning points of the year and even literally rides onto a tún in a Shetland rhyme: ${ }^{5}$ Skekla komena rina tunal swarta hosta blota bruna (Skekla [an ogress] rides into the homefield/ on a black horse with a white patch on its brow); and the folk legends of the Norwegian "wild ride" known as the Oskoreial juleskrei which was often said to be led by a female figure known as Guro Rysserover, and was said to threaten farms at Christmas. ${ }^{6}$ There is strong physical evidence (in the shape of tar crosses painted over stable and barn doors in western Norway) to prove that this last legend were treated with a high degree of belief, even in the early $20^{\text {th }}$ century. ${ }^{7}$ One might argue that the word túnridor might well be more applicable to threatening supernatural female figures like these (who all literally ride horses onto home fields), rather than to witches, even if the latter in the verse in question are said to travel by air. Indeed, the same was also often said about the Oskoreial juleskrei which are often said to be heard in the air and in the wind. In other words, 
they, too, were believed to leika lopti á, something effectively demonstrated in the final scene of Henrik Ibsen's Hormondene pa Helgeland (The Warriors at Helgeland) (I 857), where the audience hears “Åsgårdsreien suser gjennem luften” (The Åsgård Ride whistles through the air). ${ }^{8}$

\section{Notes}

I. Mitchell 200г:65-70.

2. See references in Gunnell 20I4b.

3. Gunnell 20I4a.

4. On the disir, see further Gunnell 2005.

5. See further Gunnell 200I; Jakobsen I 897:I9.

6. See further Gunnell 2005; Eike I980; Celander I943.

7. See further Eike I980.

8. Ibsen I962:8I.

\section{References}

\section{Primary Sources}

Bósa saga ok Herrauðs. Guðni Jónsson (ed.). I954. Fornaldar sögur Norðurlanda III. Akureyri: Íslendingasagnaútgáfan, 28 I-322.

Brennu-Njáls saga. Einar Ólafur Sveinsson (ed.). I954. Íslenzk fornrit XII. Reykjavík: Hið íslenzka fornritafélag.

Edda. Jónas Kristjánsson \& Vésteinn Ólason (eds). 20 I4. Eddukvœe $i$ I-II. Íslenzk fornrit. Reykjavík: Hið íslenzka fornrítafélag.

Egils saga Skalla-Grimssonar. Sigurður Nordal (ed.). I933. Egils saga Skalla-Grimssonar. Íslenzk fornrit II. Reykjavík: Hið íslenzka fornritafélag.

Eiríks saga rauða. Einar Ólafur Sveinsson \& Matthías Porðarson (eds). I935. Eiríks saga rauða. Íslenzk fornrit IV. Reykjavík: Hið íslenska fornritafélag, I93-237. 
Ibsen, Henrik. I 862. Ungdomsskuespill og historiske dramaer I $850-$ 64. I 3 th edition. Oslo: Gyldendal, Norsk forlag.

Snorri Sturluson. Anthony Faulkes (ed.). 2005. Edda. Prologue and Gylfaginning. Second ed. London: Viking Society for Northern Research.

Piðranda páttr ok Pórhalls. Bragi Halldórsson et al. (eds). I987. Íslendingar sögur. Reykjavík: Svart á hvítu, 2253-2255.

Porleifs páttr jarlsskálds. Jónas Kristjánsson (ed.). I956. Porleifs páttr jarlsskálds. Jónas Kristjánsson (ed.). I956. Eyfirðinga sogur. Íslenzk fornrit IX. Reykjavik: Hið íslenzka fornritafélag, 2I3-29.

\section{Secondary Sources}

Celander, Hilding. I943. Oskoreien och besläktade föreställningar i äldre och nyare nordisk tradition. In Saga och sed, 7 I-I 75.

Eike, Christine. I980. Oskoreia og ekstaseriter. In Norveg 23, 227-309.

Gunnell, Terry. 200 . Grýla, Grýlur, “Grøleks” and Skeklers. Medieval Disguise Traditions in the North Atlantic? In Arv. Nordic Yearbook of Folklore, 33-54.

Gunnell, Terry. 2005. The Season of the Disir. The Winter Nights and the Disarblót in Early Scandinavian Belief. In Cosmos I6 (2000), I I 7-I 49 .

Gunnell, Terry. 20I4a. 'Magical Mooning' and the 'Goatskin Twirl'. 'Other' Kinds of Female Magical Practices in Early Iceland. In T. Tangherlini (ed.). Nordic Mythologies. Interpretations, Intersections, and Institutions. The Wildcat Canyon Advanced Seminars. Mythology, vol.r. Berkeley and Los Angeles: North Pinehurst Press, I33-I 53.

Gunnell, Terry. 20I4b. Nordic Folk Legends, Folk Traditions and Grave Mounds. The Value of Folkloristics for the Study of Old Nordic Religions. In E. Heide \& K. Bek-Pedersen (eds.). New Focus on Retrospective Methods. Resuming Methodological Discussions. Case Studies from Northern Europe. Folklore Fellows Communications, 307. Helsinki: Suomalainen Tiedeakatemia/ Academica Scientiarum Fennica, I7-4I. 
Jakobsen, Jakob. I 897. Det norrøne sprog på Shetland. Copenhagen: W. Prior.

Mitchell, Stephen A. 200I. Warlocks, Valkyries and Varlets. A Prolegomenon to the Study of North Sea Witchcraft Terminology. In Cosmos. The Journal of the Traditional Cosmology Society I7:I, 59-8I. 
